\title{
Correction to: Coronial Inquests, Indigenous Suicide and the Colonial Narrative
}

\author{
Belinda Carpenter ${ }^{1} \cdot$ Megan Harris $^{1}$ - Steph Jowett ${ }^{1}$. Gordon Tait ${ }^{1}$. \\ Rebecca Scott Bray ${ }^{2}$
}

Published online: 25 August 2021

(c) Crown 2021

\section{Correction to: Critical Criminology https://doi.org/10.1007/s10612-021-09578-w}

In the original publication of the article, the Coroner's name was mistakenly identified as "Alistair Pope." The correct name is "Alastair Hope."

The original article has been corrected.

Publisher's Note Springer Nature remains neutral with regard to jurisdictional claims in published maps and institutional affiliations.

The original article can be found online at https://doi.org/10.1007/s10612-021-09578-w.

Belinda Carpenter

b.carpenter@qut.edu.au

1 School of Justice, Faculty of Law, Queensland University of Technology (Gardens Point), Brisbane, QLD, Australia

2 Department of Sociology and Social Policy, Faculty of Arts, University of Sydney, Sydney, NSW, Australia 